\section{Germination and Seed Viability of Norway Maple Cultivars, Hybrids, and Species}

\author{
Janine R. Conklin ${ }^{1,3}$ and James C. Sellmer ${ }^{2}$
}

AdDitional IndEX wORDs. Acer platanoides, Acer truncatum $\times$ platanoides, invasive

Summary. Norway maple (Acer platanoides), 15 cultivars, and two hybrids were assessed for 3 years to evaluate seed germination (e.g., growth chamber, open landscape, and forest) and viability in an initial attempt to understand their invasive potential. Differences in germination were observed among the cultivars over the study. Low to moderate germination was found in growth chambers $(0 \%-35 \%)$. Lower germination was found at open landscape $(0 \%-23 \%)$ and forest floor sites $(0 \%-18 \%)$. Inconsistent viability was observed among cultivars across the seed lots. Viability testing with tetrazolium chloride under two protocols revealed that seed viability was higher than germination and that viability alone was not a good estimate of germination potential. Differences in the accuracy of viability testing procedures were also observed. Short-term germination and viability studies provide only limited information to characterize the possible invasiveness of cultivars.

I nvasive plant species are considered threats to the biodiversity of natural areas (Morin, 1999; U.S. Department of the Interior, 1999; Wilcove et al., 1998) and some estimates suggest that they make up 8\% to $47 \%$ of the plants in each state (Westbrooks, 1998). One way that invasive plants displace natives and harm natural ecosystems is by escaping cultivation and germinating at undesirable locations (Meyer and Tchida, 1999). Such viable seeds of invasive plant species may persist in the seed bank for several years (Moore, 1972; Webb et al., 2001). Once germinated, these plants reduce native plant populations and create landscape changes over time (Webb and Kaunzinger, 1993).

Norway maple is one species that has been listed as potentially invasive.

\footnotetext{
This paper is submitted in partial fulfillment of the requirements for the $\mathrm{PhD}$ of the senior author.

The mention of a trademark, proprietary product, or vendor does not constitute a guarantee or warranty of the product by the Pennsylvania State University and does not imply its approval to the exclusion of other products or vendors that also may be suitable.

Special thanks to the Holden Arboretum and the Dawes Arboretum for the use of their plant collections, to the Pennsylvania Landscape and Nursery Association for supporting this work, and to Rick Bates and Rob Berghage for internally reviewing this paper.

Department of Horticulture, Pennsylvania State University, 310 Tyson Building, University Park, PA 16802

${ }^{1}$ Graduate Assistant.

${ }^{2}$ Associate Professor.

${ }^{3}$ Corresponding author. E-mail: jrs1030@psu.edu.
}

Ecological researchers have suggested woodlots by outcompeting native trees and reducing wildflower diversity under its canopy (Munger, 2003; Randall and Marinelli, 1996; Rhoads and Block, 2005; Webb and Kaunzinger, 1993). At the Drew University Forest Preserve (Madison, NJ), Webb et al. (2001) reported that norway maple seed banks consisting of long-lived and short-lived seeds were capable of establishing in the forest (Webb and Kaunzinger, 1993).

To address the potential invasiveness of suspected landscape plants, it is crucial that biologic traits of germination and viability be collected for cultivars of alleged invasive species. By determining the biologic potential of suspect species and their cultivars, less active and threatening cultivars may be defined and could be recommended for landscape use (Wheeler and Starrett, 2001). The purpose of this research was to determine germination and seed viability of norway maple cultivars to further understand each cultivar's possible invasiveness. that it has escaped to alter forests and

\section{Materials and methods}

Plant material and site SElECTION. Norway maple species, interspecific hybrids 'Keithsform' and 'Warrenred' (Acer truncatum $\times$ platanoides), and norway maple cultivars Columnare, Crimson King, Emerald Queen, Erectum, Faasen's Black, Fairview, Globosum, Greenlace, Reitenbachii, Royal Red, Rubrum, Schwedleri, Summershade, Superform, and Undulatum seed lots were collected annually and evaluated for 1 year each over the 3-year study (2004-06). Because of the challenge of selecting sites that possessed several of each cultivar of similar growth stages and age at a single location, the Holden Arboretum [Kirtland, $\mathrm{OH}$ (lat. $41^{\circ} 36^{\prime} \mathrm{N}$, long. $81^{\circ} 18^{\prime} \mathrm{W}$, USDA Hardiness Zone 5)], Dawes Arboretum [Newark, $\mathrm{OH}$ (lat. $39^{\circ} 58^{\prime} \mathrm{N}$, long. $82^{\circ} 24^{\prime} \mathrm{W}$, USDA Hardiness Zone 6)], and Pennsylvania State University [University Park, PA (lat. $40^{\circ} 48^{\prime} \mathrm{N}$, long. $77^{\circ} 51^{\prime} \mathrm{W}$, USDA Hardiness Zone 6)] were chosen based on the presence of selected cultivars.

SEED HARVESTING AND PREPARATION. About 1000 samaras of every cultivar (one to three plants/cultivar) were harvested by hand and bulked in bags to provide uniform seed lots during 2004, 2005 , and 2006. Samaras were dried and cleaned of debris on greenhouse benches to eliminate contamination. Fully expanded samaras of every cultivar were then used in germination and viability experiments. "Deformed samaras," defined as samaras that appeared to contain no seed, or whose seed appeared not fully expanded, were not used in this study (Fig. 1).

GROWTH CHAMBER GERMINATION. Five replications of eight seeds/replication of each cultivar, hybrid, and species were randomly chosen and soaked in tap water overnight at room temperature for imbibition. Seeds were then cold

\begin{tabular}{llll}
\hline $\begin{array}{l}\text { Units } \\
\begin{array}{l}\text { To convert U.S. to SI, } \\
\text { multiply by }\end{array}\end{array}$ & U.S. unit & SI unit & $\begin{array}{l}\text { To convert SI to U.S., } \\
\text { multiply by }\end{array}$ \\
\hline 3.1833 & $\mathrm{fl} \mathrm{oz} / 1000 \mathrm{ft}^{2}$ & $\mathrm{~L}^{\circ} \mathrm{ha}^{-1}$ & 0.3141 \\
2.54 & inch $(\mathrm{es})$ & $\mathrm{cm}$ & 0.3937 \\
25.4 & inch $(\mathrm{es})$ & $\mathrm{mm}$ & 0.0394 \\
48.8243 & lb $/ 1000 \mathrm{ft}^{2}$ & $\mathrm{~kg} \cdot \mathrm{ha}^{-1}$ & 0.0205 \\
$\left({ }^{\circ} \mathrm{F}-32\right) \div 1.8$ & ${ }^{\circ} \mathrm{F}$ & ${ }^{\circ} \mathrm{C}$ & $\left(1.8 \times{ }^{\circ} \mathrm{C}\right)+32$
\end{tabular}




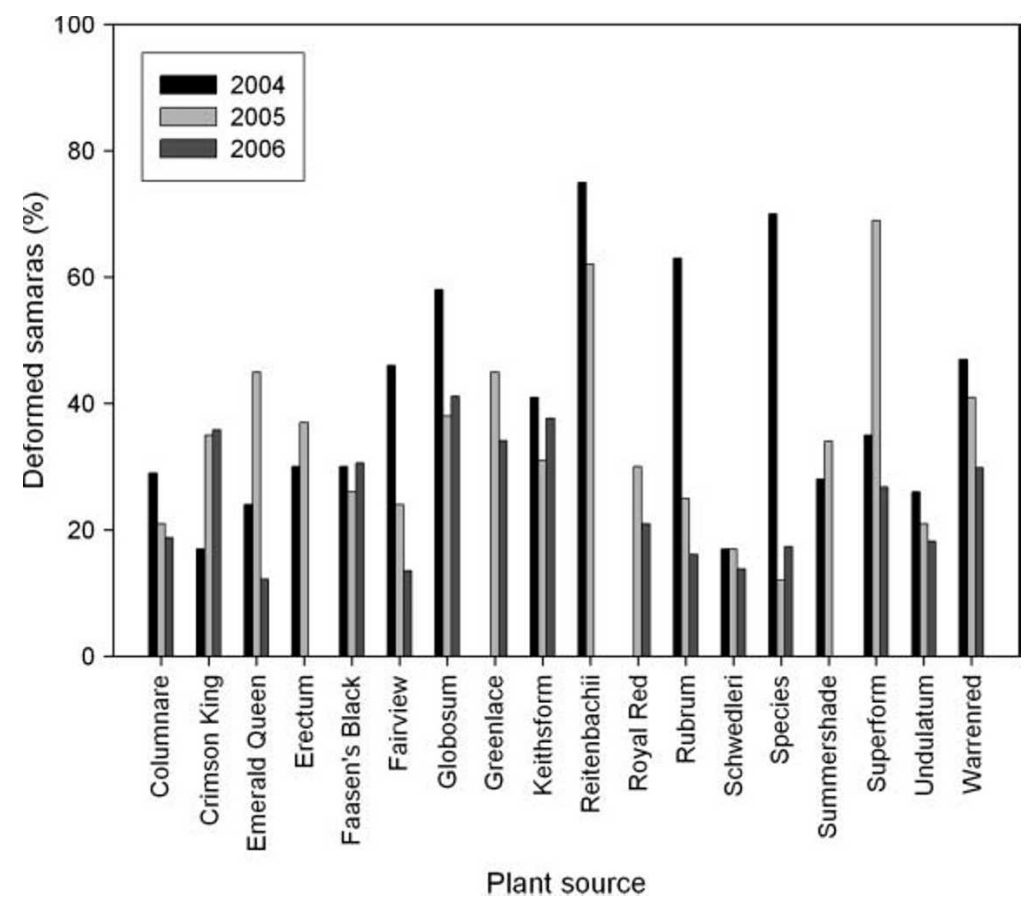

Fig. 1. Deformed samaras of norway maple cultivars, hybrids, or species for individual seed crop years (2004-06). Cultivars Keithsform and Warrenred are interspecific hybrids (Acer truncatum $\times$ platanoides).

stratified at $5{ }^{\circ} \mathrm{C}$ for $90 \mathrm{~d}$ to break dormancy (Olson and Gabriel, 1989). After this period, a completely randomized design was used to sow seeds in community flats (19 Jan. 2005, 11 Jan. 2006, and 10 Jan. 2007). Seeds were hand sown at a depth of 1 to $3 \mathrm{~cm}$ (Olson and Gabriel, 1989) in a soilless media (Sunshine Mix 4; Sun Gro Horticulture, Bellevue, WA) and were then placed in growth chambers maintained at optimal conditions of $5^{\circ} \mathrm{C}$. Seeds were watered as needed and exposed to a 12-h photoperiod with fluorescent lights (Baskin and Baskin, 1998; Olson and Gabriel, 1989). After $84 \mathrm{~d}$, germination rates were recorded (12 May 2005, 15 May 2006 , and 2 May 2007). "Germination" was defined as the emergence of a radicle or plumule.

OPEN LANDSCAPE GERMINATION. Germination experiments were conducted at the Landscape Management Research Center Pot-in-Pot Nursery (University Park, PA) to define rates at an open site subject to fluctuating environmental conditions. Ground beds with native soil, a Hagerstown silt loam (Braker 1981), a Typic Hapludalf (Bouma et al., 2001), were amended by incorporating $8 \mathrm{~cm}$ of sphagnum peatmoss and perlite (Sunshine Mix 4) to produce a uniform seed bed for germination. In the fall (8 Nov. 2004, 31 Oct. 2005, and 1 Nov. 2006), five replications of eight seeds/replication of each norway maple cultivar, hybrid, and species were sown at a depth of 1 to $3 \mathrm{~cm}$ (Olson and Gabriel, 1989) in a completely randomized design.

During the first season, each replication was confined in a plastic mesh bag $(10 \times 10 \mathrm{~cm}$, mesh size $2 \times$ $3 \mathrm{~mm})$. Mesh bags were enclosed in two hardware cloth strips $(120 \times 15$ $\mathrm{cm}$, mesh size $1 \times 1 \mathrm{~cm}$ ) and planted in the bed to protect the seeds from animal predation. The perimeter of the bed was then enclosed with hardware cloth to further prevent seedbed disruption. Overwintered seeds were assessed the following spring (1 June 2005) for germination. Seeds were overwintered for an additional year to assess germination over an extended period of time. Beds were weeded by hand ( 1 June 2005, 5 July 2005, and $16 \mathrm{May} 2006$ ) and $1.5 \mathrm{fl} \mathrm{oz} / 1000 \mathrm{ft}^{2}$ of glyphosate (Roundup; Monsanto, St. Louis) was applied as a direct spray to spot treat unwanted weeds in the seed bed (7 July 2005 and 19 Aug. 2005)

For the subsequent two seasons (2005-06), the experimental set up slightly changed to reduce the potential for disease and weed seed germination. Germination beds were sterilized with $8.0 \mathrm{lb} / 1000 \mathrm{ft}^{2}$ dazomet (Basamid; BASF Corp., Research Triangle Park, NC) and tested for dissolution of dazomet before sowing seeds. Dissolution of dazomet was tested by sowing 12 indicator seeds [lettuce (Lactuca sativa) or oat (Avena sativa)] within and outside the beds to observe germination. Indicator seeds that germinated within the treated area ensured that dazomet gas had subsided and that the norway maple crop could be planted. Norway maple seeds were then planted as previously described, with the exception that seeds were loosely sown within wooden frames in rows without confinement in plastic mesh bags and hardware cloth units. A poison bait trap was placed in the center of each wooden frame to prevent rodent predation on the seed. Bamboo stakes were arched and plastic deer netting (mesh size $3 \times 3 \mathrm{~cm}$ ) was stapled over the frame to exclude animal activity in each bed. Seeds were overwintered and germination was assessed the following spring (1 June 2006 and 24 May 2007).

Forest GERMINATION. Germination experiments were conducted under a forest canopy located at the Russel E. Larson Agricultural Research Center (Rock Springs, PA). Preparation and the experimental design were similar to the open landscape site except that the germination beds were not amended or sterilized. Leaf litter was initially removed with rakes, competing canopy tree roots were severed with pruners, and the soil was loosened with hand tools to create a uniform seedbed. No cultivation or herbicides were applied and the beds remained leaf litter free throughout the duration of this experiment. Trials were conducted each fall (8 Nov. 2004, 1 Nov. 2005, and 1 Nov. 2006) and germination was assessed the following spring (1 June 2005, I June 2006, and 24 May 2007).

Seed Viability. Two seed viability testing protocols were used, a traditional tetrazolium chloride (TTC) test (Hartmann et al., 2002) and a modified TTC protocol described by Grabe (1970). The TTC solution (2,3,5-triphenyltetrazolium chloride; Sigma-Aldrich, St. Louis) 
confirms the presence of viable living embryos through the reduction of TTC to formazan, which stains living tissues red (Ellis et al., 1985; Hartmann et al., 2002). Forty seeds of every cultivar, hybrid, and species were randomly selected for each test. Undeveloped seeds were excluded from viability tests. With the traditional TTC test, three replications were conducted on an annual basis (18-19 Oct. 2004, 20-21 Oct. 2005, and 29 Sept. and 4 Oct. 2006) and two replications were conducted with Grabe's (1970) protocol later in the study period (14-16 Dec. 2005 and 29 Sept. and 4 Oct. 2006). Using the traditional TTC procedure, 'Erectum', 'Summershade', and 'Reitenbachii' were tested only in 2004-05; 'Crimson King', 'Faasen's Black', 'Greenlace', and 'Royal Red' were tested only in 2005-06; and 'Superform' was tested only in 2006. All other cultivars were tested in all 3 years. With Grabe's (1970) method, 'Erectum', 'Reitenbachii', and 'Summershade' were tested only in 2005 , and 'Emerald Queen' and 'Superform' were tested only in 2006. All other cultivars were tested in both years.

For both viability procedures, pericarps with wings were soaked in tap water at room temperature for a few hours to soften and aid in pericarp removal by hand. Seeds were then soaked overnight at room temperature followed by seedcoat removal to allow for metabolic activation and absorption of the TTC solution. The solution was prepared by dissolving TTC powder in tap water to produce a $2 \%$ solution at a pH between 6 and 8 for adequate staining. Seeds were soaked in the $2 \%$ TTC solution at room temperature for $22 \mathrm{~h}$ and were then removed from solution and visually assessed for viability.

Viable and nonviable seeds were defined in a different manner for the traditional TTC test and Grabe's (1970) protocol. For the traditional TTC test, "nonviable seeds" were classified as those that remained unstained and "viable seeds" were defined as seeds that stained any region of the seed red. For Grabe's (1970) protocol, "nonviable seeds" were defined as having more than one-half of the cotyledons unstained, more than the radicle tip unstained, the embryo totally unstained, necrotic spots or injured tissues at critical regions, seeds that stained a grayish red or purplish red, or totally flaccid tissues. "Viable seeds" were classified as well developed seeds that possessed little to no necrotic regions or injured tissues at critical locations, red stained seeds, and turgid tissues.

Statistical analysis. Means and standard errors were calculated for germination (e.g., growth chamber, open landscape, and forest) and viability of seed lots collected for each of the 3 years. Annual germination for each of the 3 years and differences in germination from year to year at each location were subjected to one-way analysis of variance using SAS's GLM procedure (version 9.1; SAS Institute, Cary, NC) to find out if cultivars influenced these variables. Duncan's multiple range test was then used to make pairwise comparisons of the means if cultivars were significant $(P \leq 0.05)$. The highest germination observed under all test conditions and viability with the traditional TTC test or Grabe's (1970) protocol were annually assessed for each of the 3 years with Pearson's correlation to find out if a statistically significant linear relationship existed between germination and viability $(P \leq 0.05)$.

A square transformation was employed on cultivar germination at the open site in 2006 to assure homogeneity of variance and was only applied in 2006 because heteroscedasticity was observed on untransformed data. This transformation was employed when making pairwise comparisons; however, reported means and standard errors were of untransformed data. Statistics were performed using SAS (version 9.1) and graphs were generated with SigmaPlot (version 9.0; Systat Software, San Jose, CA).

\section{Results and discussion}

Several norway maples that are readily available in the trade were included in this study: 'Columnare', 'Crimson King', 'Emerald Queen', 'Globosum', 'Keithsform', 'Fairview', 'Royal Red', 'Summershade', 'Superform', 'Warrenred', and the species. Additionally, 'Faasen's Black', 'Greenlace', 'Erectum', 'Reitenbachii', 'Rubrum', 'Schwedleri', and 'Undulatum' were studied, but are not readily available in the trade. Plants that are not readily available may be economically valuable and worthy of reconsideration by the industry if low germination and viability rates are discovered.

GROWTH CHAMBER GERMinATION. When assessing the potential invasiveness of any plant species, germination is one important factor that must be considered (Wilson and Mecca, 2003; Wilson et al., 2004). Previous research on cultivars of landscape species labeled as potentially invasive have classified high germination from $70 \%$ to $100 \%$ and low germination from $0 \%$ to $<30 \%$ (Anisko and Im, 2001; Lovinger and Anisko, 2004; Meyer and Tchida, 1999; Wilson et al., 2004). In keeping with these defined germination rates, high rates in this study were set at a range from $75 \%$ to $100 \%$, moderate rates from $25 \%$ to $74 \%$, and low rates from $0 \%$ to $24 \%$.

Germination among norway maple cultivars significantly differed in 2004 and 2005 (Fig. 2, A and B) and did not significantly differ in 2006 (data not shown). All cultivars germinated at low to moderate rates each year of the 3-year study. Of the cultivars that germinated over the study period, the highest germination rates occurred in 2004. Slightly reduced rates were observed in 2005 and little to no germination was observed in 2006. 'Crimson King', 'Faasen's Black', 'Globosum', 'Greenlace', 'Reitenbachii', 'Summershade', 'Superform', and the species did not germinate over the 3-year study (Fig. 2, A and B). Comparable variation in germination among cultivars has been reported for barberry (Berberis) and buckthorn (Rhamnus) (Lehrer et al., 2006; Wheeler and Starrett, 2001).

Similar germination $(0 \%-35 \%$; 0\%-25\%) was observed among the cultivars during the first 2 years of the study (Fig. 2, A and B). Germination was much lower $(0 \%-13 \%)$ in the third year. Germination may have been lower in the third year because of a system failure experienced (19 Jan. 2007 and 12 Mar. 2007) in two of the growth chambers. This system failure caused air temperatures to rise to 44 and $38{ }^{\circ} \mathrm{C}$, respectively, for a few hours and may have damaged seeds.

OPEN LANDSCAPE AND FOREST GERMINATION. No germination occurred in 2004 when seeds were enclosed in plastic mesh bags. For 

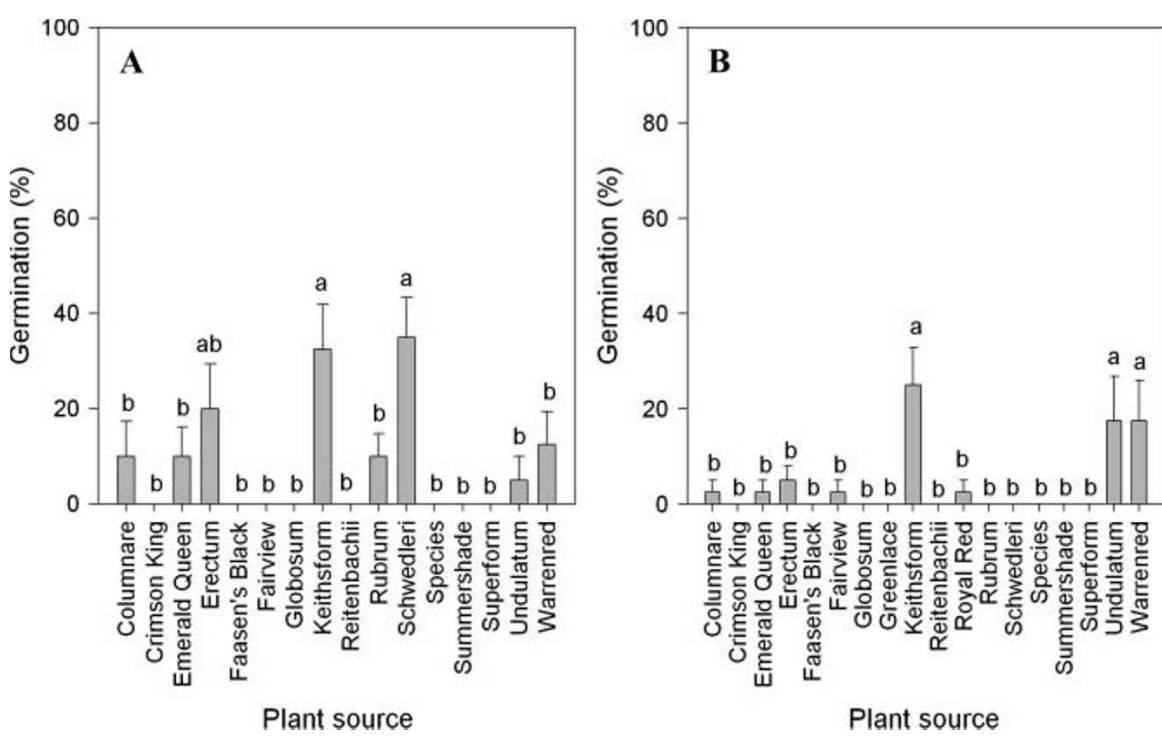

Fig. 2. Growth chamber germination for norway maple cultivars, hybrids, or species with the (A) 2004 and (B) 2005 seed lot. Cultivars Keithsform and Warrenred are interspecific hybrids (Acer truncatum $\times$ platanoides). All values are means $\pm \mathrm{SE}$. Mean separation of cultivars (lowercase letters) by Duncan's multiple range test at $P \leq 0.05$.

this reason, a follow-up germination experiment was conducted on the most productive and highest germinating 2004 seed ('Keithsform'). This experiment was performed as described under growth chamber germination with or without plastic mesh bags to decide whether bags inhibited germination. For this study, it was concluded that the bags did not inhibit germination, although germination was low (3\% with bags, $0 \%$ without bags). Watanabe et al. (2002) conducted similar field germination studies on apple of peru (Nicandra physalodes) in fiberglass mesh bags and found that seeds germinated in bags.

The Pennsylvania State University Plant Disease Clinic (University Park, PA) identified two fungal pathogens, Alternaria and Mucor, and possible insect damage among the seeds recovered for the field germination experiments in 2004. Alternaria or Mucor may have infected and killed seeds before or after germination (Agarwal and Sinclair, 1997; Chelkowski and Visconti, 1992). Because the open landscape site was not sterilized with chemicals such as dazomet in 2004, germination may have been lower because of the presence of these pathogenic soil microorganisms.

All germination at the open landscape site was categorized as low during 2005 and 2006, with the highest germination occurring in 2005 for most cultivars. Germination rates in 2005 ranged from $3 \%$ to $23 \%$ (Fig. 3). 'Fairview' (23\%) germinated at a significantly greater rate than all cultivars. 'Warrenred' (8\%), 'Erectum' (3\%), 'Keithsform' (3\%), and the species $(3 \%)$ were the only other seed lots to germinate at this time and did not significantly differ from seed that did not germinate (Fig. 3). In 2006, no significant differences in germination were found (data not shown). 'Fairview' (15\%), 'Keithsform' $(3 \%)$, and 'Rubrum' (3\%) were the only cultivars to germinate and show similar rates from 2005 to 2006 .

In the forest, germination was low for all cultivars and did not show significant differences in 2005; however, significant differences were observed in 2006 (data not shown). In 2005, 'Columnare', 'Emerald Queen', 'Fairview', and 'Globosum' were the only cultivars to germinate at rates between $3 \%$ and $4 \%$. Germination slightly increased between $1 \%$ and $15 \%$, respectively, from 2005 to 2006 for 'Emerald Queen' and 'Fairview', which were the only two cultivars to germinate. 'Fairview' (18\%) germinated at a significantly greater rate than 'Emerald Queen' (5\%) in 2006.

Over the 3-year study, the highest range in germination rates was observed in the growth chambers $(0 \%-35 \%)$ and at the open landscape site $(0 \%-23 \%)$ for cultivars. The lowest range in germination rates was found in the forest $(0 \%-18 \%)$. 'Fairview' displayed the highest rates at the open landscape site, lower rates in the forest, and the lowest rates in the growth chambers. 'Columnare', 'Emerald Queen', 'Erectum', 'Globosum', 'Royal Red', 'Rubrum', and the species performed similarly under all test conditions. 'Keithsform' and 'Warrenred' did not germinate in the forest, demonstrated slightly higher rates at the open site, and even higher rates in the growth chambers. 'Schwedleri' and 'Undulatum' germinated only in the growth chambers. 'Crimson King', 'Faasen's Black', 'Greenlace', 'Reitenbachii', and 'Summershade' did not germinate under any test conditions.

Differences in germination under various conditions demonstrate that cultivars need to be tested under a wide range of conditions to define the full germination potential of each cultivar. Although all cultivars showed low rates at both outdoor sites, some may still merit caution for use in the landscape. Without further extensive germination trials over time, there remains a question to the possible invasiveness of these cultivars.

Germination did not differ among cultivars from year to year in the growth chambers or open landscape; however, rates did vary from year to year in the forest for only four cultivars. 'Fairview' showed the greatest variation over 2 years in the forest. 'Globosum', 'Emerald Queen', and 'Columnare' displayed minor changes. These observations differ with similar studies on miscanthus (Miscanthus) under optimal conditions (Meyer and Tchida, 1999) and agree with similar research on guelder rose (Viburnum opulus) at an outdoor garden plot (Jones and Wheelwright, 1987). Additionally, variation noted in norway maple cultivar germination in the forest over time differed with similar findings on red maple (Acer rubrum) (Tremblay et al., 1996). Reasons for such differences in norway maple cultivar germination reported here and Meyer and Tchida's (1999) or Tremblay et al. (1996) may be due to environmental or physiologic conditions such as seed dormancy (Qaderi 


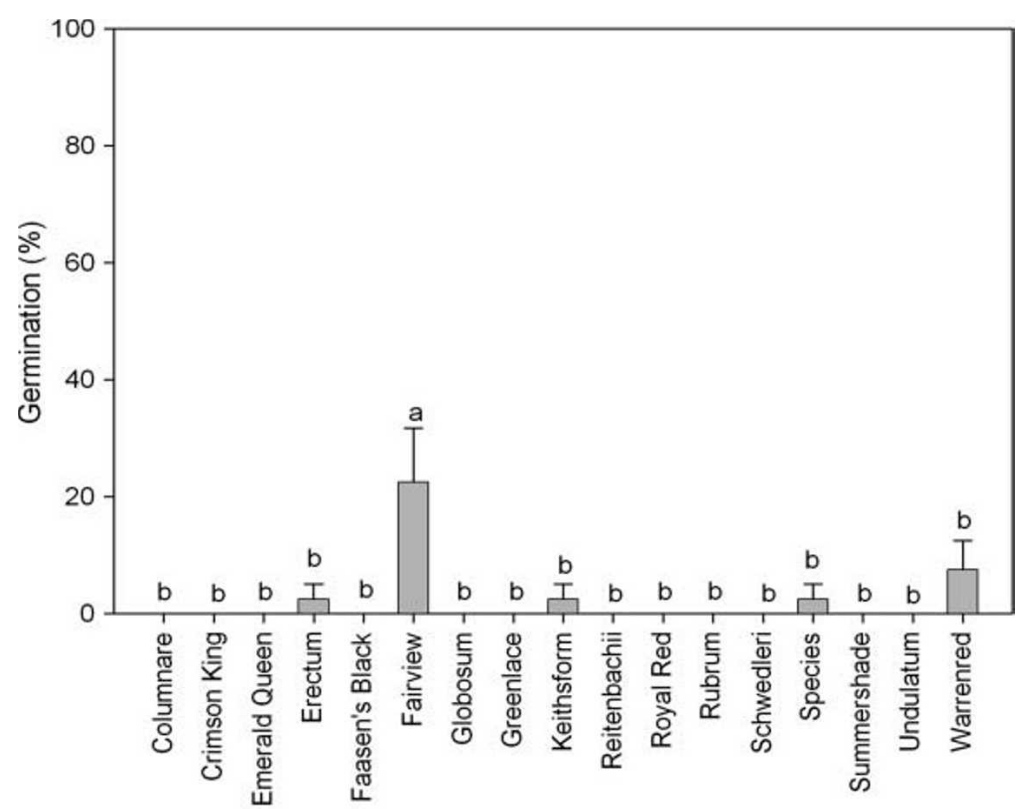

Plant source

Fig. 3. Open landscape germination for norway maple cultivars, hybrids, or species with the 2005 seed lot. Cultivars Keithsform and Warrenred are interspecific hybrids (Acer truncatum $\times$ platanoides). All values are means \pm SE. Mean separation of cultivars (lowercase letters) by Duncan's multiple range test at $P \leq 0.05$.

and Cavers, 2000). The variation in germination rates reveals the need to test seeds over several years to observe the full germination potential for accurately assessing the possible invasiveness of each cultivar.

Differences among germination rates at each study site for norway maple cultivars might be because of cultivar-specific responses to varying environmental conditions (KostelHughes et al., 2005). Seeds that germinate best in the laboratory under optimal conditions will most likely germinate in the field, while those that show weak germination in the laboratory may not (Willan, 1985). Most cultivars from our trials germinated at low rates or not at all at the open landscape site; however, some cultivars germinated better although at low rates at the open site.

Seed viability. For individual seed crop years (2004-06), the traditional TTC test revealed that all cultivars were viable and rates varied each year for most cultivars. Viability ranged from $13 \%$ to $100 \%$ in 2004 , from $3 \%$ to $100 \%$ in 2005 , and from $45 \%$ to $100 \%$ in 2006 (Fig. 4 ). 'Columnare' (13\%-98\%), 'Rubrum' (13\%-98\%), 'Undulatum' (38\%95\%), and 'Schwedleri' (3\%-88\%) had the most inconsistency in yearly viability. 'Warrenred' (95\%-100\%),
'Summershade' $(95 \%-100 \%)$, and 'Keithsform' (88\%-100\%) had consistently high viability each year. 'Reitenbachii' (58\%-65\%) was consistently moderate in viability during the study. All other cultivars had high viability for 1 or 2 years, except 'Superform' (45\%), which was moderately viable for only 1 year (Fig. 4).

Each year, viability of most cultivars was much higher with the traditional TTC test when compared with rates of Grabe's (1970) procedure (Figs. 4 and 5). Using Grabe's (1970) procedure, individual seed crop years (2005-06) revealed that viability was highly variable each year for most cultivars. Viability ranged from $7 \%$ to $75 \%$ in 2005 and from $3 \%$ to $93 \%$ in 2006 . 'Rubrum' and 'Schwedleri' were not viable in 2005 and 'Faasen's Black' and 'Superform' were not viable in 2006. All cultivars showed moderate to low viability over the study except 'Fairview' (93\%), 'Keithsform' (83\%), and the species $(75 \%)$, which produced high rates for 1 year. 'Globosum' (18\%-25\%), 'Columnare' $(8 \%-10 \%)$, and 'Crimson King' (3\%-10\%) showed few changes in yearly viability. 'Fairview' $(28 \%-$ 93\%), 'Keithsform' (40\%-83\%), 'Rubrum' (0\%-68\%), and 'Warrenred' $(18 \%-53 \%)$ had the most fluctuations (Fig. 5).
High variation in viability from year to year is not uncommon, and similar results in viability have been found for the sycamore maple (Acer pseudoplatanus) and norway maple (Eicke, 1984). Reasons for high variation in viability may be because of nonuniform seed lots, mechanical damage (Grabe, 1970), environmental conditions, or species-specific responses (Hartmann et al., 2002). No sign of microbe attack was observed among the seeds and environmental conditions were the same for all cultivars. Because the seed was bulked among the replications for each cultivar, there may be a chance that nonuniform seed lots were created or that damage occurred in the bulking process (Grabe, 1970), although caution was practiced to prevent this occurrence.

Different viability results with testing methods merits caution when choosing viability testing protocols to study alleged invasive species and their cultivars or hybrids. Although differences in viability may not always be apparent with various tests, they sometimes are different, as was demonstrated with most norway maple cultivars that showed much higher viability with the traditional TTC test compared with Grabe's procedure. No statistically significant linear correlation was observed between germination and viability with the traditional TTC test or Grabe's procedure for each of the 3 years of the study (data not shown). Despite the lack of correlation between germination and viability, we believe that Grabe's procedure better represents the viability of the cultivars. We believe this conclusion because Grabe's procedure placed tighter definitions on what is viable and the two test results produced obvious differences in positive tests. This belief is further justified in that the cultivar germination was much lower over the study than the viability represented by the traditional and liberal TTC test. In examining viability, we suggest that future researchers consider the strictness of the testing regime they use.

Viability tests are best performed in conjunction with germination experiments to better define the reproductive potential of seeds over time (Drewitz and DiTomaso, 2004). Previous research suggests that the 


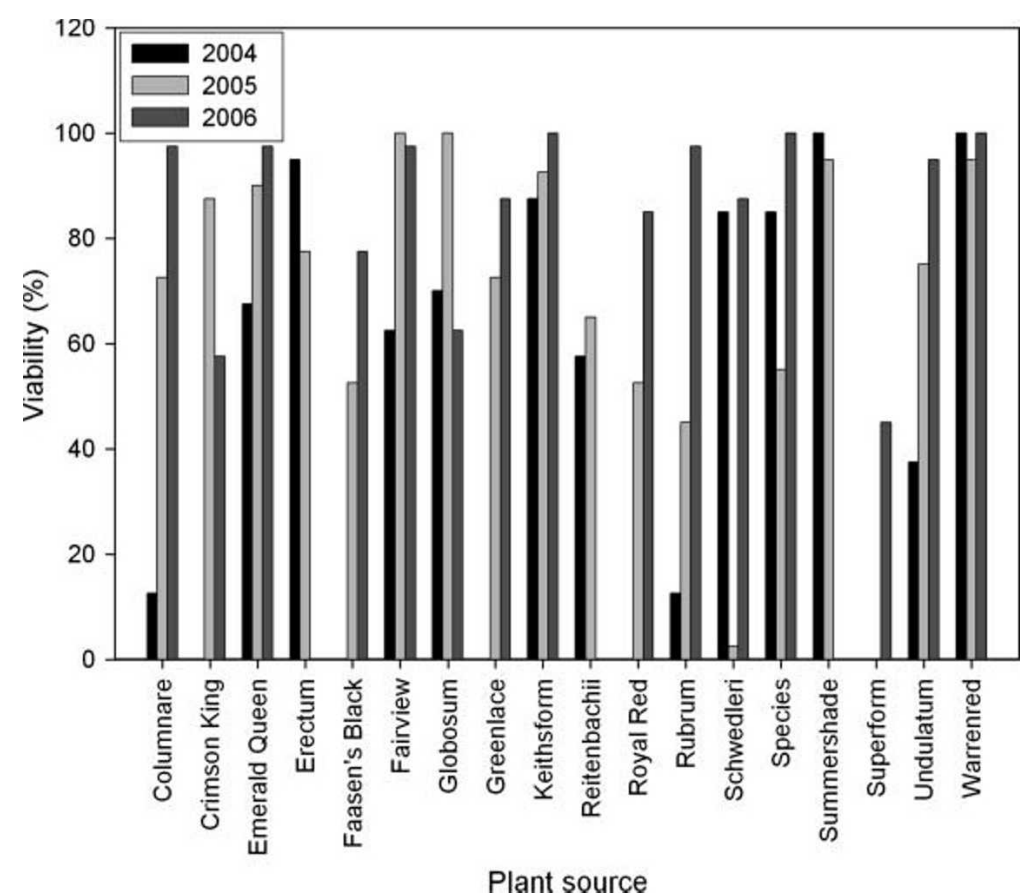

Fig. 4. Traditional tetrazolium test viability for individual seed crop years (2004-06) of norway maple cultivars, hybrids, or species. Cultivars Keithsform and Warrenred are interspecific hybrids (Acer truncatum $\times$ platanoides). All values are means. SES were not calculated for norway maple cultivars because of small sample sizes.

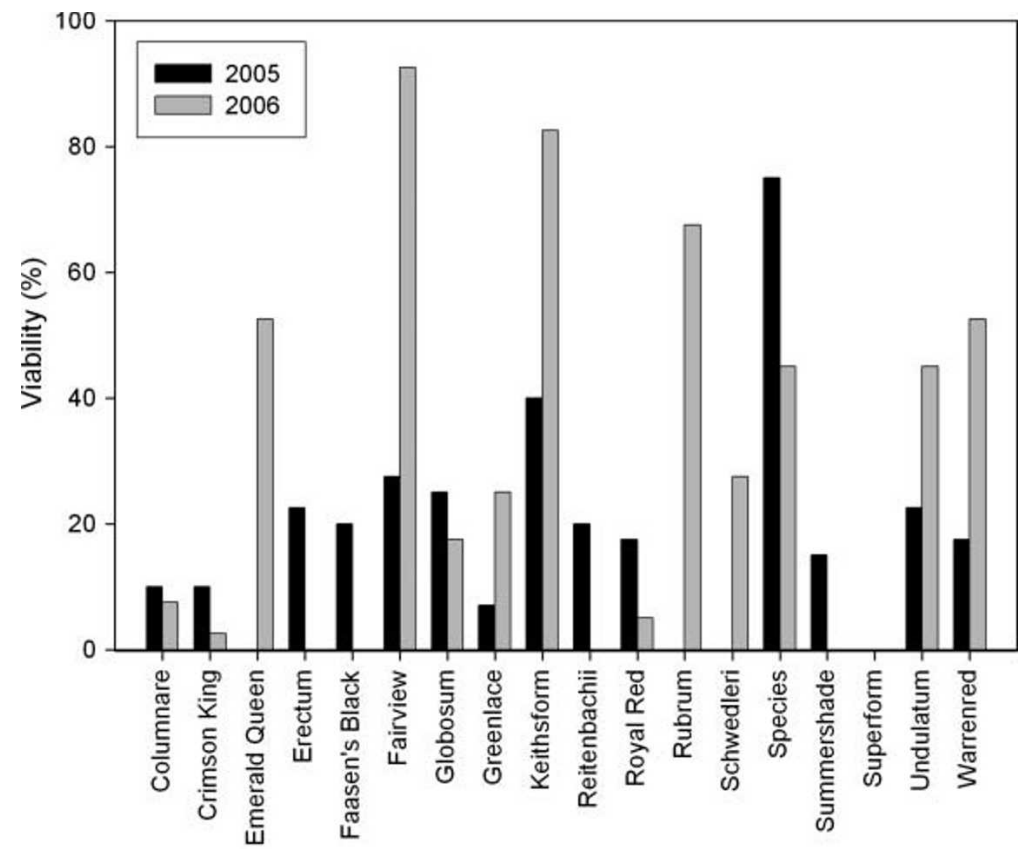

Plant source

Fig. 5. Grabe's (1970) procedure viability for individual seed crop years (2005-06) of norway maple cultivars, hybrids, or species. Cultivars Keithsform and Warrenred are interspecific hybrids (Acer truncatum $\times$ platanoides). All values are means. SES were not calculated for norway maple cultivars because of small sample sizes.

results for both tests should be similar to one another, within $3 \%$ to $12 \%$ (Moore, 1972; Wilson et al., 2004). Higher differences do not automatically mean that the tetrazolium test was conducted in error and may occur because of dormant seeds, incorrect tetrazolium or germination testing techniques, hard seeds, nonuniform seed lots, or low-quality seeds (Grabe, 1970; Moore, 1972). For the purposes of this study, differences in rates of both experiments $\leq 10 \%$ were considered to be similar, while those $\geq 15 \%$ were considered to be very different.

Viability with Grabe's (1970) procedure and the highest germination observed under all test conditions for individual seed crop years were similar for many norway maple cultivars. 'Columnare' and 'Crimson King' had similar rates for 2 years. 'Faasen's Black', 'Fairview', 'Greenlace', 'Warrenred', 'Royal Red', 'Rubrum', 'Schwedleri', 'Summershade', 'Superform', and 'Undulatum' showed similar rates for 1 year. All other cultivars showed variation between viability and germination. Similarities between viability and germination of plants agree with similar findings on jubatagrass (Cortaderia jubata) and the butterfly bush (Buddleja) (Drewitz and DiTomaso, 2004; Wilson et al., 2004).

An explanation for the variation between viability and germination for some norway maple cultivars may be seed dormancy and maturity. Seeds at various maturity levels or of the same species harvested at varying positions on the mother plant may show differences in dormancy (Baskin and Baskin, 1998). Seed dormancy is not always removed by following procedures to break dormancy (Gutormson and Patin, 2002). Although cultivars were stratified for the desired period, seeds may have experienced different dormancy levels and some may have remained dormant, which resulted in differences between germination and viability.

In general, germination (e.g., growth chamber, open landscape, and forest) and viability varied among norway maple cultivars for each study year. From year to year, seed viability varied, whereas germination in the growth chambers, open landscape, and forest was similar for most cultivars. Viability testing with TTC under two protocols showed that seed viability was higher than germination and revealed that different viability results may be observed with different testing protocols. To fully understand the germination and seed viability pattern of the cultivars, further longterm studies (5-10 years) would be appropriate. Without extended studies, 
questions remain regarding the possible invasiveness of the cultivars.

To provide a clearer picture of each norway maple cultivar's invasiveness, more representative cultivars could also be researched to define germination under growth chamber, open landscape, and forest conditions along with seed viability. Cultivars' competitive abilities, pollen viability, level of seed predation, and distance of seed dispersal could also be defined to aid in determining each norway maple cultivar's possible invasiveness.

\section{Literature cited}

Agarwal, V.K. and J.B. Sinclair. 1997. Principles of seed pathology. 2nd ed. CRC Press, Boca Raton, FL.

Anisko, T. and U. Im. 2001. Beware of butterfly bush. Amer. Nurse 194:46-49.

Baskin, C.C. and J.M. Baskin. 1998. Seeds: Ecology, biogeography, and evolution of dormancy and germination. Academic Press, San Diego.

Bouma, T.J., R.D. Yanai, A.D. Elkin, U. Hartmond, D.E. Flores-Alva, and D.M. Eissenstat. 2001. Estimating age-dependent costs and benefits of roots with contrasting life span: Comparing apples and oranges. New Phytol. 150:685-696.

Braker, W.L. 1981. Soil survey of Centre County, Pennsylvania. U.S. Dept. Agr., Washington, DC.

Chelkowski, J. and A. Visconti. 1992. Alternaria: Biology, plant diseases and metabolites. Elsevier, Amsterdam, Netherlands.

Drewitz, J.J. and J.M. DiTomaso. 2004. Seed biology of jubatagrass (Cortaderia jubata). Weed Sci. 52:525-530.

Eicke, G. 1984. Report of the forest tree seed committee working group on tetrazolium 1980-1983: Comparative tests of Acer spp., Pseudotsuga menziesii and Abies spp. by tetrazolium. Seed Sci. Technol. 12:197-204.

Ellis, R.H., T.D. Hong, and E.H. Roberts. 1985. Handbook of seed technology for genebanks v.2. Intl. Board Plant Genet. Resources, Rome.

Grabe, D.F. 1970. Tetrazolium testing handbook for agricultural seeds: Contribution no. 29 to the Handbook on seed testing, Association of Official Seed Ana- lysts. Assn. Offic. Seed Analysts, North Brunswick, NJ.

Gutormson, T.J. and A.L. Patin. 2002. Sources of laboratory test result variation in warm-season grasses. Seed Technol. 24:52-61.

Hartmann, H.T., D.E. Kester, F.T. Davies, Jr., and R.L. Geneve. 2002. Plant propagation principles and practices. 7 th ed. Prentice Hall, Englewood Cliffs, NJ.

Jones, E. and N.T. Wheelwright. 1987. Seasonal changes in the fruits of Viburnum opulus, a fleshy-fruited temperatezone shrub. Can. J. Bot. 65:2291-2296.

Kostel-Hughes, F., T.P. Young, and J.D. Wehr. 2005. Effects of leaf litter depth on the emergence and seedling growth of deciduous forest tree species in relation to seed size. J. Torrey Bot. Soc. 132:5061.

Lehrer, J.M., M.H. Brand, and J.D Lubell. 2006. Four cultivars of japanese barberry demonstrate differential reproductive potential under landscape conditions. HortScience 41:762-767.

Lovinger, S. and T. Anisko. 2004. Benign Berberis. Amer. Nurse 200:36-39.

Meyer, M. and C.L. Tchida. 1999. Miscanthus Anderss. produces viable seed in four USDA hardiness zones. J. Environ. Hort. 17:137-140.

Moore, R.P. 1972. Tetrazolium staining for assessing seed quality, p. 347-366. In: W. Heydecker (ed.). Seed ecology. Pennsylvania State Univ. Press, University Park, PA.

Morin, N. 1999. Solving the invasive plant problem. Public Garden 14:16-17.

Munger, G.T. 2003. Acer platanoides. 1 June 2007. <http://www.fs.fed.us/data base/feis/plants/tree/acepla/all.html>.

Olson. D.F., Jr. and W.J. Gabriel. 1989 Acer L. maple, p. 187-194. In: C.S Schopmeyer (ed.). Seeds of woody plants in the United States. U.S. Dept. Agr. For. Serv., Washington, DC.

Qaderi, M.M. and P.B. Cavers. 2000 Variation in germination response within scotch thistle, Onopordum acanthium L., populations matured under greenhouse and field conditions. Ecoscience 7:57-65

Randall, J.M. and J. Marinelli. 1996. Invasive plants weeds of the global garden. Brooklyn Bot. Garden, Brooklyn, NY.
Rhoads, A. and T. Block. 2005. Trees of Pennsylvania: A complete reference guide. Univ. Pennsylvania Press, Philadelphia, PA.

Tremblay, M.F., Y. Mauffette, and Y. Bergeron. 1996. Germination responses of northern red maple (Acer rubrum) populations. For. Sci. 42:154-159.

U.S. Department of the Interior. 1999. Invasive species fact sheet. White House, Office Press Secretary, Washington, DC.

Watanabe, H., Y. Kasagaya, and M. Saigusa. 2002. Environmental factors affecting germination of apple of Peru. Weed Sci. 50:152-156.

Webb, S.L. and C.K. Kaunzinger. 1993. Biological invasion of the Drew University (New Jersey) forest preserve by norway maple (Acer platanoides L.). Bull. Torrey Bot. Club 120:343-349.

Webb, S.L., T.H. Pendergast, IV, and M.E. Dwyer. 2001. Response of native and exotic maple seedling banks to removal of the exotic, invasive norway maple (Acer platanoides). J. Torrey Bot. Soc. 128:141-149.

Westbrooks, R.G. 1998. Invasive plants, changing the landscape of America: Fact book. Federal Interagency Committee Mgt. Noxious Exotic Weeds, Washington, DC.

Wheeler, A.R. and M.C. Starrett. 2001. Determining the invasive potential of Rhamnus frangula 'Asplenifolia' and 'Columnaris' based on seed germination. Combined Proc. Intl. Plant Prop. Soc. 51:397-400

Wilcove, D.S., D. Rothstein, J. Dubow, A. Phillips, and E. Losos. 1998. Quantifying threats to imperiled species in the United States. Bioscience 48:607-615.

Willan, R.L. 1985. A guide to forest seed handling. Food Agr. Org. United Nations, Rome.

Wilson, S.B. and L.K. Mecca. 2003. Seed production and germination of eight cultivars and the wild type of Ruellia tweediana: A potentially invasive ornamental. J. Environ. Hort. 21:137-143.

Wilson, S.B., M. Thetford, L.K. Mecca, J.S. Raymer, and J.A. Gersony. 2004. Evaluation of 14 butterfly bush taxa grown in western and southern Florida: II. Seed production and germination. HortTechnology 14:612-618. 